\title{
Thrombin-Induced Decidual Colony-Stimulating Factor-2 Promotes Abruption-Related Preterm Birth by Weakening Fetal Membranes
}

Rachel G. Sinkey, ${ }^{*}$ Ozlem Guzeloglu-Kayisli, ${ }^{*}$ Sefa Arlier, ${ }^{* \dagger}$ Xiaofang Guo, ${ }^{*}$ Nihan Semerci, ${ }^{*}$ Robert Moore, ${ }^{\ddagger}$ Asli Ozmen, ${ }^{*}$ Kellie Larsen, ${ }^{*}$ Chinedu Nwabuobi, ${ }^{*}$ Deepak Kumar, ${ }^{\ddagger}$ John J. Moore, ${ }^{\ddagger}$ Lynn F. Buckwalder, ${ }^{\S}$ Frederick Schatz, ${ }^{*}$ Umit A. Kayisli, and Charles J. Lockwood*

From the Department of Obstetrics and Gynecology, * University of South Florida, Morsani College of Medicine, Tampa, Florida; the Department of Obstetrics \& Gynecology, ${ }^{\dagger}$ Adana City Education and Research Hospital, Adana, Turkey; the Division of Neonatology, ${ }^{\ddagger}$ Department of Pediatrics, MetroHealth Medical Center, Case Western Reserve University, Cleveland, Ohio; and the Department of Obstetrics \& Gynecology, ${ }^{\S}$ Yale University School of Medicine, New Haven, Connecticut

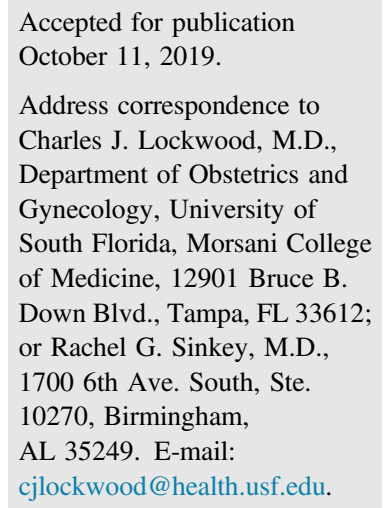

\begin{abstract}
Preterm premature rupture of membranes (PPROM) and thrombin generation by decidual cell -expressed tissue factor often accompany abruptions. Underlying mechanisms remain unclear. We hypothesized that thrombin-induced colony-stimulating factor-2 (CSF-2) in decidual cells triggers paracrine signaling via its receptor (CSF2R) in trophoblasts, promoting fetal membrane weakening and abruption-associated PPROM. Decidua basalis sections from term $(n=10)$, idiopathic preterm birth (PTB; $n=8)$, and abruption-complicated pregnancies $(n=8)$ were immunostained for CSF-2. Real-time quantitative PCR measured CSF2 and CSF2R mRNA levels. Term decidual cell (TDC) monolayers were treated with $10^{-8} \mathrm{~mol} / \mathrm{L}$ estradiol $\pm 10^{-7} \mathrm{~mol} / \mathrm{L}$ medroxyprogesterone acetate (MPA) $\pm 1 \mathrm{IU} / \mathrm{mL}$ thrombin pretreatment for 4 hours, washed, and then incubated in control medium with estradiol \pm MPA. TDC-derived conditioned media supernatant effects on fetal membrane weakening were analyzed. Immunostaining localized CSF-2 primarily to decidual cell cytoplasm and cytotrophoblast cell membranes. CSF-2 immunoreactivity was higher in abruption-complicated or idiopathic PTB specimens versus normal term specimens $(P<0.001)$. CSF2 mRNA was higher in TDCs versus cytotrophoblasts $(P<0.05)$, whereas CSF2R mRNA was $1.3 \times 10^{4}$-fold higher in cytotrophoblasts versus TDCs $(P<0.001)$. Thrombin enhanced CSF-2 secretion in TDC cultures fourfold $(P<0.05)$; MPA reduced this effect. Thrombin-pretreated TDC-derived conditioned media supernatant weakened fetal membranes $(P<0.05)$, which MPA inhibited. TDC-derived CSF-2, acting via trophoblast-expressed CSFR2, contributes to thrombininduced fetal membrane weakening, eliciting abruption-related PPROM and PTB. (Am J Pathol 2020, 190: 388-399; https://doi.org/10.1016/j.ajpath.2019.10.020)
\end{abstract}

During the luteal phase of the human menstrual cycle, increasing circulating progesterone (P4) levels induce endometrial stromal cells to undergo decidualization, converting fibroblast-like stromal cells to decidual cells. Sustained circulating P4 levels, accompanied by continuation of decidualization, are required to establish and maintain pregnancy. ${ }^{1}$ Previously, we discovered that a key feature of decidualization is increased expression of tissue factor, a transmembrane $45-\mathrm{kDa}$ glycoprotein. ${ }^{2}$ In response to vascular injury, plasma-derived factor VII binds to cell membrane-bound tissue factor, forming a tissue factor/ factor VIIa complex that fosters hemostasis by activating

Supported by the March of Dimes Foundation Ohio Prematurity Collaborative grant 134266 (C.J.L.) and the Burroughs Wellcome Fund 1015024 (J.J.M.).

Disclosures: None declared.

Current address of R.G.S., Department of Obstetrics and Gynecology, University of Alabama at Birmingham, Birmingham, AL. 
factor $\mathrm{X}$ or IX to ultimately convert prothrombin to thrombin (THR). Newly formed THR triggers the clotting cascade by converting fibrinogen to fibrin and activating platelets. ${ }^{3}$ Therefore, decidual cell-expressed THR mitigates decidual hemorrhage (ie, abruption) throughout human pregnancy. Among the cells in human term placenta, decidual cells express the highest tissue factor levels, which contrasts with the virtual absence of tissue factor immunostaining in adjacent interstitial or extravillous cytotrophoblasts (CTBs). ${ }^{4}$

As pregnancy progresses, bleeding into the decidua basalis may clinically manifest as an abruption, vaginal bleeding, or a subchorionic hematoma. ${ }^{5,6}$ Vaginal bleeding during pregnancy is associated with a $74 \%$ increased risk of preterm birth (PTB), many of which are attributable to preterm premature rupture of membranes (PPROM). ${ }^{7}$ This correlation is greatest between 22 and 32 weeks of gestation, when abruption occurs in greater than one-third of PPROM cases compared with only $0.8 \%$ of women experiencing term delivery. ${ }^{8-10}$

We previously reported that $\mathrm{P} 4$, medroxyprogesterone acetate (MPA), or 17 $\alpha$-hydroxyprogesterone treatment inhibits THR-induced fetal membrane weakening by inhibiting colony-stimulating factor (CSF)-2 production and action. ${ }^{11}$ Because the cellular source, the relevant intracellular mechanism(s), and/or paracrine target(s) underlying this finding are not known, we hypothesized that THRinduced CSF-2 in term decidual cells (TDCs) triggers paracrine signaling via its receptor (CSF2R) on trophoblast cell membranes, promoting fetal membrane weakening and abruption-associated PTB. Therefore, the current study evaluates a functional role of THR-enhanced CSF-2 secretion by human TDCs in mediating fetal membrane weakening and rupture as a prelude to PTB.

\section{Materials and Methods}

\section{Tissues}

Previously banked placental paraffin blocks containing decidua basalis, obtained from the Yale New Haven Hospital (New Haven, CT), were used in this study. Term decidua basalis biopsies were obtained from scheduled repeated cesarean deliveries (precontraction, $n=5$ ) and after the onset of labor (post-contraction, $n=5$ ). Preterm decidua basalis specimens were obtained from gestational age-matched idiopathic $(n=8)$ and abruption-complicated PTB $(n=8)$. Abruption-associated PTB specimens had a clinical diagnosis of abruption, whereas idiopathic PTB specimens displayed no clinical evidence of abruption, chorioamnionitis, or preeclampsia. This study was conducted after approval from the Yale University Human Investigation Committee and subsequently the University of South Florida Institutional Review Board (number 19472).

\section{Immunohistochemistry and HSCORE Analysis}

Paraffin sections ( $5 \mu \mathrm{m}$ thick) from formalin-fixed placentas of term and gestational age-matched idiopathic and abruption-complicated PTB pregnancies were deparaffinized in xylene and rehydrated in a descending series of ethanol, then boiled in antigen retrieval solution using citrate buffer ( $\mathrm{pH}$ 6.0), as described previously. ${ }^{12}$ After several washes in Tris-buffered saline $(\mathrm{pH}$ 7.2) and endogenous peroxidase quenching in 3\% hydrogen peroxide solution, the samples were blocked with 5\% normal goat serum (Vector Labs, Burlingame, CA) for 30 minutes and incubated overnight with a rabbit polyclonal CSF-2 antibody (Abcam, Cambridge, MA). After several washes in Tris-buffered saline, the slides were incubated with biotinylated goat anti-rabbit secondary antibody (Vector Labs) for 30 minutes, then incubated with streptavidin-conjugated peroxidase complex (Vector Labs) for 30 minutes. After several rinses in Tris-buffered saline, CSF-2 immunoreactivity was developed using diaminobenzidine (3, 3-diaminobenzidine tetrahydrochloride dihydrate; Vector Labs) as the chromogen, and sections were counterstained with hematoxylin. To identify trophoblasts and decidual cells, a second set of serial sections were double immunostained sequentially for cytokeratin-7 (a trophoblast marker; Dako Cytomation, Carpinteria, CA) and vimentin (a decidual marker; Abcam), as described. ${ }^{13}$ Diaminobenzidine (brown) for cytokeratin and Vector RED for vimentin (Vector Labs) were used as chromogens. Serial sections of fetal membranes $(n=4)$ and decidua basalis $(n=3)$ of term pregnancies were also immunostained using mouse monoclonal CSF2R $\alpha$ (Santa Cruz Biotechnology, Inc., Dallas, TX) or rabbit monoclonal phosphorylated STAT5 (Cell Signaling, Danvers, MA) antibodies. For negative controls, appropriate normal rabbit or mouse IgG isotype was used at the same concentration as each primary antibody (Table 1). Immunoreactivity for CSF-2 was assessed by histologic score (HSCORE) analysis, a semiquantitative method that evaluates the intensity and the number of immunostained cells. ${ }^{12}$ Three blinded observers (R.G.S., S.A., N.S.) assigned HSCOREs, and the mean score was used for each sample.

\section{Term Decidual Cell Culture}

Aliquots of frozen leukocyte-free TDCs, isolated from term placentas from uncomplicated pregnancies undergoing repeated cesarean deliveries, were grown to confluence, as described. $^{4,14}$ Confluent TDCs were primed in serumcontaining medium with $10^{-8} \mathrm{~mol} / \mathrm{L}$ estradiol used as control ( $\mathrm{E}_{2}$; Sigma-Aldrich, St. Louis, MO) or $10^{-8} \mathrm{~mol} / \mathrm{L}$ $\mathrm{E}_{2}+10^{-7} \mathrm{~mol} / \mathrm{L}$ MPA, a mixed progestin-glucocorticoid (Sigma-Aldrich) for 7 days, then exchanged to serum freedefined medium containing $\mathrm{E}_{2}$ or $\mathrm{E}_{2}+\mathrm{MPA} \pm 1 \mathrm{U} / \mathrm{mL}$ THR (Sekisui Diagnostics, Stamford, CT) for 6 and 24 hours. In parallel experiments, primed TDCs were also 
Table 1 Detailed Description of Antibodies Used for IHC and Immunoblotting (WB Analysis)

\begin{tabular}{|c|c|c|c|}
\hline Antibody name & Catalog no./company & Species & Dilution/procedure \\
\hline CSF-2 & ab9741/Abcam & Rabbit & $5 \mu \mathrm{g} / \mathrm{mL} / \mathrm{IHC}$ \\
\hline Cytokeratin -7 & M7018/Dako Cytomation & Mouse & $1: 600 / \mathrm{IHC}$ \\
\hline $\mathrm{CSF} 2 \mathrm{R} \alpha$ & sc21764/Santa Cruz Biotechnology, Inc. & Mouse & $1: 50 / \mathrm{IHC}$ \\
\hline Phosphorylated STAT5 & 9359/Cell Signaling & Rabbit & $1: 250 /$ IHC and $1: 1000 /$ WB analysis \\
\hline Total STAT5 & 94205/Cell Signaling & Rabbit & $1: 1000 /$ WB analysis \\
\hline p65 NF- $\kappa B$ & $8242 /$ Cell Signaling & Rabbit & 1:1000/WB analysis \\
\hline Phosphorylated p65 NF-кB & 3033/Cell Signaling & Rabbit & 1:1000/WB analysis \\
\hline ERK1/2 MAPK & $4348 /$ Cell Signaling & Rabbit & 1:1000/WB analysis \\
\hline Phosphorylated ERK1/2 MAPK & 9106/Cell Signaling & Mouse & 1:1000/WB analysis \\
\hline p38 MAPK & 9212/Cell Signaling & Rabbit & 1:1000/WB analysis \\
\hline
\end{tabular}

CSF2R $\alpha$, CSF-2 receptor $\alpha$; ERK, extracellular signal-regulated kinase; IHC, immunohistochemistry; MAPK, mitogen-activated protein kinase;/ WB, Western blot.

treated with $10^{-8} \mathrm{~mol} / \mathrm{L} \mathrm{E}_{2}+10^{-7} \mathrm{~mol} / \mathrm{L}$ dexamethasone, a pure glucocorticoid (Sigma-Aldrich), or $10^{-7} \mathrm{~mol} / \mathrm{L}$ Organon 2058, a pure progestin (Merck, Whitehouse Station, NJ) $\pm 1 \mathrm{U} / \mathrm{mL}$ THR for 6 hours. RNA was isolated after 6 hours of incubation of TDCs, whereas after 24 hours of treatment of TDCs, the conditioned medium supernatant (CMS) was collected for enzyme-linked immunosorbent assay analysis. Modeled after our previous fetal membrane weakening studies, ${ }^{11}$ TDCs were incubated with $\mathrm{E}_{2} \pm \mathrm{THR}$ or $\mathrm{E}_{2}+\mathrm{MPA} \pm \mathrm{THR}$ for 4 hours, then washed with phosphate-buffered saline to remove residual THR, then incubated for an additional 24 hours in serum free-defined medium containing the aforementioned steroids. Collected CMS was used for fetal membrane strength testing to analyze the direct effect of TDCs on fetal membrane weakening.

In a set of parallel experiments, TDCs primed with $\mathrm{E}_{2}+\mathrm{MPA}$ for 7 days were preincubated with $2 \times 10^{-5}$ mol/L PD98059 [an extracellular signal-regulated kinase (ERK) 1/2 mitogen-activated protein kinase (MAPK)

Table 2 Detailed Description of Primers Used for Real-Time Quantitative PCR

\begin{tabular}{ll}
\hline Primer/probe name & TaqMan assay ID \\
\hline CSF-2 & Hs00929873_m1 \\
CSF2RA & Hs00531296_g1 \\
IL-1 $\beta$ & Hs0155410_m1 \\
IL-6 & Hs00985639_m1 \\
IL-8 & Hs00174103_m1 \\
MMP-3 & Hs00968305_m1 \\
MMP-7 & Hs01042796_m1 \\
MMP-9 & Hs00234579_m1 \\
$\beta-A c t i n$ & Hs99999903_m1 \\
\hline
\end{tabular}

CSF2RA, CSF-2 receptor A; ID, identifier; MMP, matrix metalloproteinase. inhibitor] or $\pm 2 \times 10^{-5} \mathrm{~mol} / \mathrm{L} \mathrm{SB} 203580$ (a p38 MAPK inhibitor) or $\pm 10^{-6} \mathrm{~mol} / \mathrm{L}$ Bay-III $(\mathrm{NF}-\kappa \mathrm{B}$ activation inhibitor III; Millipore, San Diego, CA) for 45 minutes, then treated with $1 \mathrm{U} / \mathrm{mL}$ THR for 6 hours for real-time quantitative PCR (qPCR) analyses to identify relevant signaling pathways involved in THR-induced $C S F-2$ expression.

\section{Trophoblast Cell Cultures}

Total RNA from previously isolated and cultured CTBs and syncytiotrophoblasts $\left(\mathrm{STBs}^{15-17}\right.$; obtained from uncomplicated pregnancies and repeated cesarean deliveries at term; kindly provided by Dr. Seth Guller, Yale College of Medicine, New Haven, CT) were used to compare endogenous expression of $C S F-2$ and its receptor CSF $2 R A$ in CTBs, STBs, and TDCs.

To analyze CSF-2-mediated signaling pathway(s), BeWo cells (a trophoblastic cell line provided by Dr. Hana Totary-Jain, University of South Florida, Morsani College of Medicine, Tampa, FL) were cultured in Dulbecco's modified Eagle's medium and Ham F12 with $10 \%$ fetal bovine serum and $100 \mathrm{U} / \mathrm{mL}$ penicillin and $100 \mu \mathrm{g} / \mathrm{mL}$ streptomycin (Invitrogen, Carlsbad, CA). Confluent BeWo cells were incubated for 24 hours in serum-free media, then treated for 15 minutes with control or $10 \mathrm{ng} / \mathrm{mL}$ recombinant human (rh)-CSF-2 (R\&D Inc., Minneapolis, MN), followed by protein extraction for immunoblotting analysis of signaling molecules.

\section{RRT and Real-Time Quantitative PCR}

Using an RNAqueous-Micro isolation kit (Ambion, Austin, TX), total RNA was isolated from primary cultures of human TDCs, CTBs, and STBs as well as choriodecidual explant cultures, per manufacturer's instructions. Reverse 

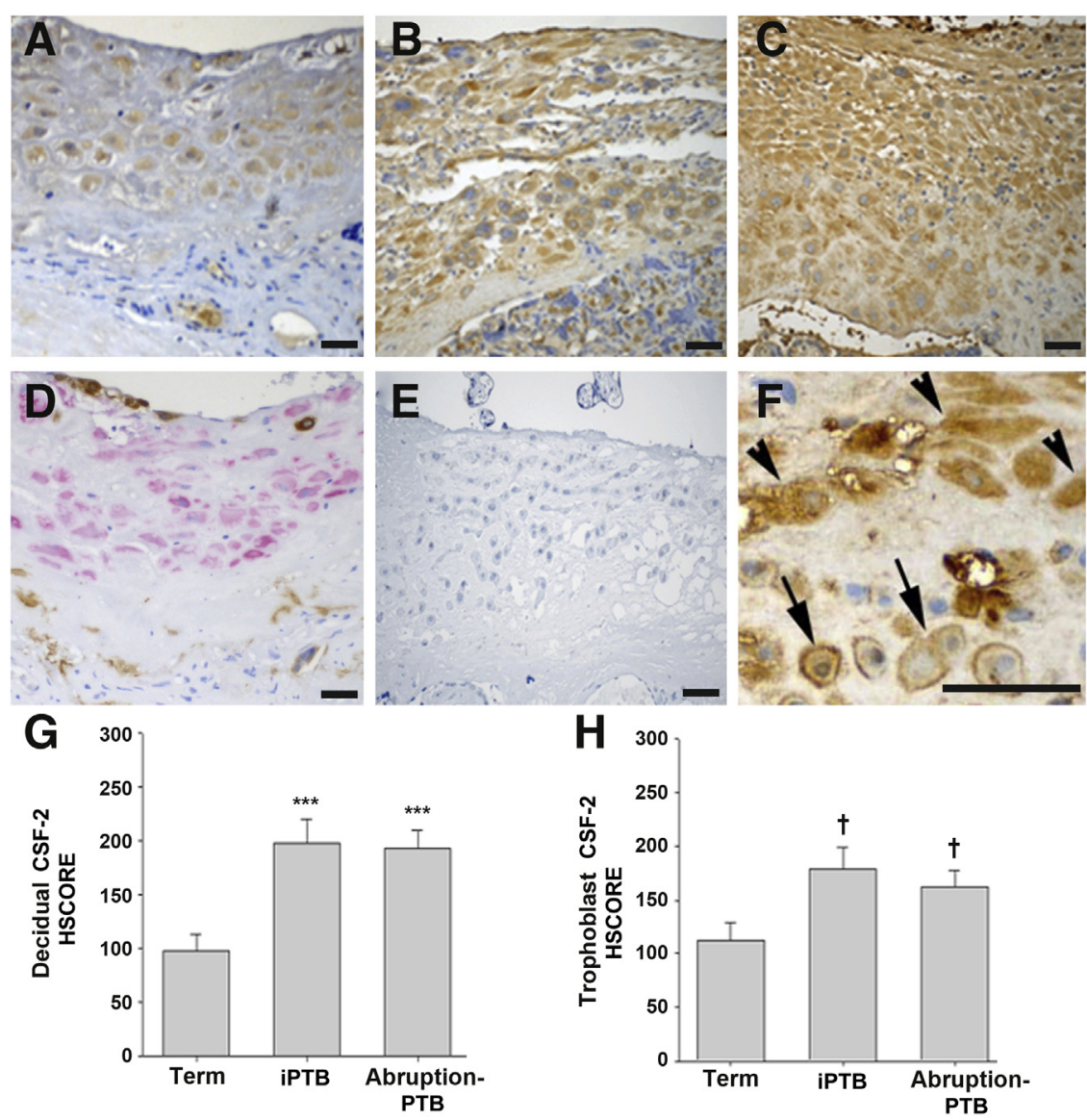

Figure 1 In situ regulation of CSF-2 immunostaining at the maternal-fetal interface. A-C: Expression levels of CSF-2 immunoreactivity in decidual cells and trophoblasts at the maternalfetal interface in term (A), idiopathic preterm birth (PTB; B), and abruption-associated PTB (C) specimens. D: Vimentin and cytokeratin double immunostaining is seen in red and brown to identify decidual and trophoblast cells, respectively. E: Negative control immunostaining for CSF2 in term specimens using appropriate non-specific IgG isotype as the same concentration as CSF-2 primary antibody. F: Higher magnification of CSF2 immunoreactivity in the cytoplasm of decidual cells (arrowheads) and trophoblasts cell membrane (arrows) in abruption-associated PTB specimens. $\mathbf{G}$ and H: Histologic score (HSCORE) levels of CSF2 immunoreactivity in decidual cells (G) and trophoblasts $(\mathbf{H})$ at the maternal-fetal interface in term specimens or idiopathic PTB (iPTB) and abruption-associated PTB specimens. Data are expressed as means \pm SEM ( $\mathbf{G}$ and $\mathbf{H}) . n=10(\mathbf{A})$; $n=8$ (B and $\mathbf{C}) .{ }^{* * *} P<0.001$ versus term in decidual cells; ${ }^{\dagger} P<0.05$ versus term in trophoblasts. Scale bars $=30 \mu \mathrm{m}(\mathbf{A}-\mathbf{F})$. transcription was performed using the Retroscript (Invitrogen), as follows: template RNA and random primers were incubated at $65^{\circ} \mathrm{C}$ for 5 minutes (to eliminate any secondary structures). After adding the buffer and enzyme, the reaction was performed at $42^{\circ} \mathrm{C}$ for 1 hour. qPCR was performed using TaqMan gene expression assays for CSF2, CSF2RA, matrix metalloproteinase $(M M P) 3,7$, or 9 , as well as $I L-1 B$, $I L-6$, or $I L-8$ (Applied Biosystems, Foster City, CA) (Table 2). All samples were run in triplicate. Expression of the target mRNAs was normalized to $\beta$-actin mRNA levels and the $2^{-\Delta \Delta C T}$ (cycle threshold) method was used to calculate relative expression levels.

\section{Enzyme-Linked Immunosorbent Assay}

Enzyme-linked immunosorbent assay (R\&D Inc.) was performed, as described, ${ }^{18}$ to measure CSF-2 secretion levels in the CMS collected from TDC $(n=8)$ cultures treated with $10^{-8} \mathrm{~mol} / \mathrm{L} \mathrm{E}_{2}$ or $10^{-8} \mathrm{~mol} / \mathrm{L} \mathrm{E}_{2}+10^{-7} \mathrm{~mol} / \mathrm{L} \mathrm{MPA} \pm 1$ $\mathrm{U} / \mathrm{mL}$ THR for 24 hours.

\section{Immunoblotting}

Whole cell lysates from BeWo cells treated for 15 minutes with control or $10 \mathrm{ng} / \mathrm{mL}$ rh-CSF-2 (R\&D Inc.) were subjected to SDS-PAGE with $7.5 \%$ or $10 \%$ Tris-HCl gel (Bio-Rad, Hercules, CA) and then transferred to a nitrocellulose membrane. Blocking was performed with $10 \%$ nonfat dried milk, then membrane was incubated overnight with rabbit anti-phosphorylated or total (T) antibodies against STAT5, STAT3, p65 NF-кB, ERK1/2, p38 MAPKs, or AKT (Cell Signaling) (Table 1). After washing with Trisbuffered saline with $0.1 \%$ Tween 20 (pH 7.2), secondary antibody labeling was performed by incubating the membrane with horseradish peroxidase-conjugated goat antirabbit IgG or horse anti-mouse IgG (Vector Labs). An enhanced chemiluminescence kit (GE Healthcare, Piscataway, NJ) was used to detect immunoblot bands. All membranes were stripped and reprobed with horseradish peroxidase-labeled rabbit anti- $\beta$-actin antibody (Cell Signaling).

\section{Fetal Membrane Strength Testing}

Portions of fetal membranes $(n=4)$, obtained from uncomplicated term repeated cesarean deliveries, were strength tested within transwell inserts using a rupture testing apparatus. To test fetal membrane tensile strength, fetal membranes were secured between horizontal plates. A 1-cm, motor-driven, spherical-head plunger was driven 

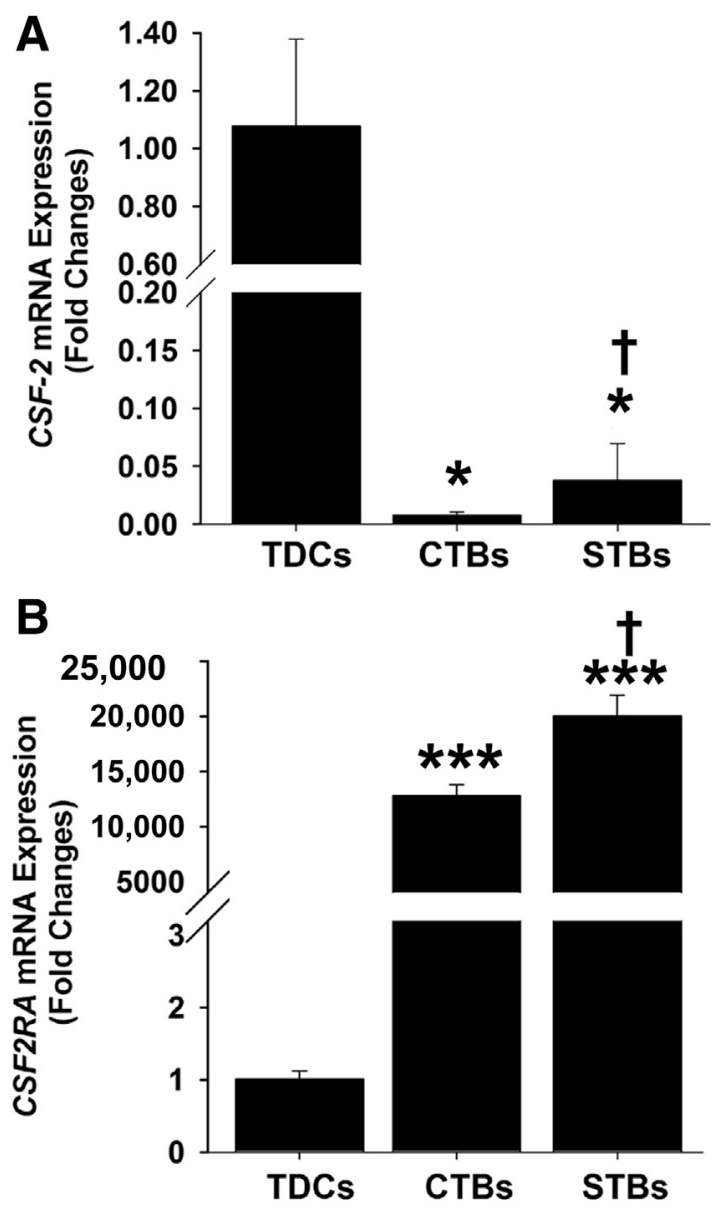

Figure 2 In vitro comparative analysis of CSF2 and its receptor, CSF2RA, expression. A: CSF2 mRNA levels in primary cultured term decidual cells (TDCs), cytotrophoblasts (CTBs), and syncytiotrophoblasts (STBs) by realtime quantitative PCR (qPCR). B: Expression of CSF-2 receptor, CSF2RA, mRNA in TDCs, CTBs, and STBs by qPCR. CSF2 (A) and CSF2RA (B) mRNA levels were determined and normalized to $\beta$-actin. Data are expressed as means $\pm \operatorname{SEM}(\mathbf{A}$ and $\mathbf{B}) . n=3$ (A and $\mathbf{B}) .{ }^{*} P<0.05,{ }^{* *} P<0.001$ versus TDCs; ${ }^{\dagger} P<0.05$ versus CTBs.

perpendicular to the fetal membrane against the fetal amnion. Fetal membrane displacement and force in Newtons were recorded continuously until rupture. Fetal membrane strength testing was performed on term, prelabor specimens incubated in CMS collected from TDCs cultured in $\mathrm{E}_{2} \pm$ THR or $\mathrm{E}_{2}+\mathrm{MPA} \pm \mathrm{THR}$, as described in Term Decidual Cell Culture.

\section{Choriodecidual Explant Culture}

The fetal membrane (three experimental repeats) was dissected from the placenta collected from a nonlaboring woman with intact membrane at 33 weeks who underwent caesarean delivery for presumptive placenta accreta, which was not confirmed by histopathologic examination, then rinsed with phosphate-buffered saline to remove residual blood. After removing the amnion, the choriodecidual tissue was minced into small pieces and randomly distributed into a 12-well culture plate containing Dulbecco's modified Eagle's medium and Ham F12 supplemented with 5\% fetal bovine serum and $1 \%$ penicillin-streptomycin solution for 24 hours. The following day, the medium was carefully removed and treated with control or 10 or $100 \mathrm{ng} / \mathrm{mL}$ rhCSF-2 for 6 hours for RNA isolation and subsequent qPCR analysis.

\section{Statistical Analysis}

Normality of data was investigated using the KolmogorovSmirnov test. Immunohistochemistry HSCOREs and qPCR and fetal membrane strength results were normally distributed and analyzed by one-way analysis of variance, followed by post-hoc Tukey testing. Enzyme-linked immunosorbent assay results for CSF-2 secretion were not normally distributed and were analyzed using the KruskalWallis test, followed by the post-hoc Student-NewmanKeuls test. Immunoblotting data from BeWo cell cultures and qPCR data from choriodecidual explants were analyzed using a $t$-test. Analyses were performed using SigmaStat version 3.0 (Systat Software, San Jose, CA). $P<0.05$ was considered statistically significant.

\section{Results}

Increased CSF-2 Immunostaining at the Maternal-Fetal Interface, Obtained from Abruption-Associated PTB

Representative CSF-2 immunostaining from term specimens $(n=10)$ and gestational age-matched idiopathic (spontaneous; $n=8)$ and abruption-associated $(n=8)$ PTB samples are shown in Figure 1, A-C. Vimentin (red color) and cytokeratin (brown color) double immunostaining were used to differentiate decidual cells and trophoblasts, respectively (Figure 1D). Compared with term specimens (Figure 1A), abruption-associated PTB samples displayed stronger CSF-2 immunostaining, whereas CSF-2 immunostaining was similar in idiopathic and abruptionassociated PTB samples (Figure 1, B and C). No immunoreactivity was observed in negative control slides (Figure 1E). HSCORE analysis confirmed significantly higher CSF-2 HSCOREs in idiopathic and abruptionassociated PTB versus term specimens with respect to decidual cells $(P<0.001)$ (Figure $1 \mathrm{G})$ and trophoblasts $(P<0.05)$ (Figure $1 \mathrm{H})$. No differences in CSF-2 expression were observed at the maternal-fetal interface between term precontraction and term post-contraction specimens (data not shown). However, examination of immunostained slides under $\times 100$ magnification localized CSF-2 immunostaining primarily in the cytoplasm of decidual cells and the cell membrane of trophoblasts (Figure 1F), suggesting a potential in situ paracrine interaction mediated by binding of decidual-secreted CSF- 2 to trophoblastexpressed CSF2R. 
In Vitro Comparative Analysis of CSF2 and CSF2RA Expression in TDCs, CTBs, and STBs

To extend the immunohistochemical observations of cytoplasmic and membranous CSF-2 immunostaining in decidual cells and trophoblasts, respectively (Figure $1 \mathrm{~F}$ ), mRNA expression levels of $C S F-2$ and its receptor CSF2RA were evaluated in TDC, CTB, and STB cultures by qPCR. This analysis revealed 29-fold higher CSF2 mRNA levels in TDCs compared with SBTs $(P<0.05)$, and $C S F 2$ mRNA levels were barely detectable in CTBs $(P<0.05)$ (Figure 2A). In contrast, CSF2RA mRNA levels are 13,000and 20,000-fold higher in CTB and STB cultures, respectively, compared with TDC cultures $(P<0.001)$ (Figure 2B). Immunostaining of fetal membranes $(n=4)$ and decidua basalis $(n=3)$ from human placental specimens, obtained from term uncomplicated pregnancies, confirmed in situ expression of CSF2R $\alpha$ in chorionic extravillous trophoblasts in fetal membrane (Supplemental Figure S1) and interstitial cytotrophoblasts and multinucleated trophoblastic cells in decidua basalis (Supplemental Figure S2).

\section{In Vitro Regulation of CSF2 mRNA and Protein Levels by THR in TDCs}

Increased abruption-related immunostaining for CSF-2 and higher $C S F 2$ expression in TDC cultures led to examination of the influence of THR, as a marker for abruption on CSF2 mRNA levels in TDC cultures. Compared with $E_{2}$ as a control, THR enhanced CSF 2 mRNA levels by fivefold and fourfold in $\mathrm{E}_{2}$ and $\mathrm{E}_{2}+$ MPA incubations, respectively $(n=7 ; P<0.05)$ (Figure 3A). Although the addition of MPA did not affect basal CSF2 mRNA levels, it significantly reduced THR-induced CSF 2 expression compared with $\mathrm{E}_{2}+$ THR [fold changes, $3.43 \pm 0.47$ versus $5.42 \pm 0.60$ (means \pm SEM); $P<0.05]$.

In cultured TDCs, compared with $\mathrm{E}_{2}, \mathrm{E}_{2}+$ MPA did not affect CSF-2 protein levels. However, THR induced CSF-2 protein secretion by 25 - and 10 -fold in cultures treated with $\mathrm{E}_{2}$ and $\mathrm{E}_{2}+\mathrm{MPA}$, respectively $(P<0.05)$ (Figure $\left.3 \mathrm{~B}\right)$. To investigate the effect of steroids in THR-induced CSF2 mRNA expression in TDCs, cells were also treated with dexamethasone, a pure glucocorticoid, or Organon 2058, a pure progestin. ${ }^{12}$ Similar to MPA treatment, coincubation with dexamethasone or Organon 2058 significantly reduced THR-induced CSF2 mRNA levels 2.2- or 1.9-fold, respectively $(n=6 ; P<0.05$ ) (Figure $3 \mathrm{C}$ ) compared with $\mathrm{E}_{2}+$ THR-treated TDC cultures, suggesting that MPAmediated inhibition of THR-induced CSF 2 gene expression is facilitated by either glucocorticoid or progesterone actions.

\section{Fetal Membrane Strength Testing}

Addition of the human recombinant CSF-2 on the chroriodecidual side of the fetal membranes causes fetal membrane
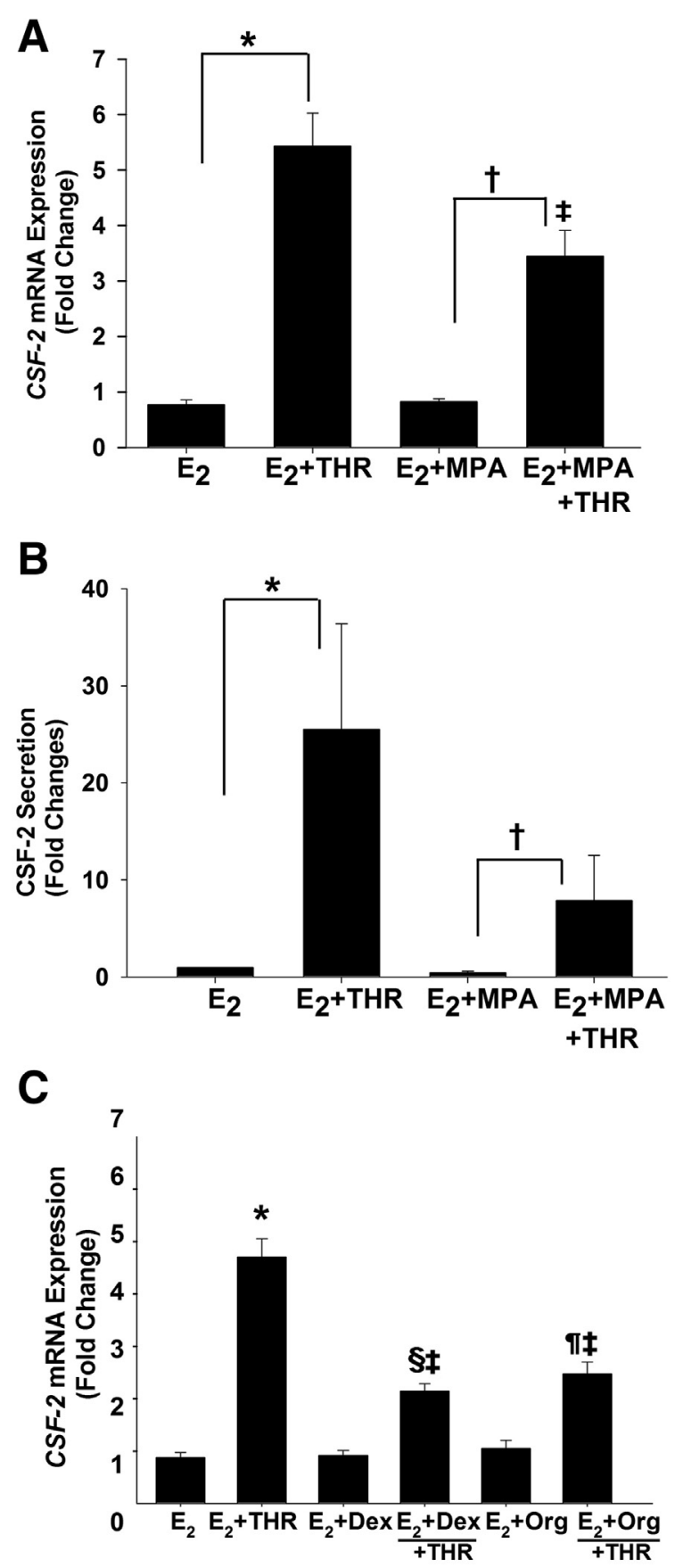

Figure 3 Thrombin (THR)-mediated in vitro regulation of CSF2 mRNA and protein levels in term decidual cell cultures. A: Confluent leukocyte-free term decidual cells were primed with estradiol $\left(E_{2} ; 10^{-8} \mathrm{~mol} / \mathrm{L}\right)$ or $\mathrm{E}_{2}+$ medroxyprogesterone acetate (MPA; $\left.10^{-7} \mathrm{~mol} / \mathrm{L}\right)$, then treated with $E_{2}+$ THR $(1 \mathrm{U} / \mathrm{mL})$ or $E_{2}+$ MPA + THR. CSF2 mRNA levels were measured by real-time quantitative PCR and normalized to $\beta$-actin. B: Secreted CSF-2 levels were measured by enzyme-linked immunosorbent assay in conditioned media collected from primed term decidual cells treated with $\mathrm{E}_{2}\left(10^{-8} \mathrm{~mol} / \mathrm{L}\right)$, $E_{2}+\operatorname{THR}(1 \mathrm{U} / \mathrm{mL}), E_{2}+$ MPA $\left(10^{-7} \mathrm{~mol} / \mathrm{L}\right)$, or $E_{2}+$ MPA + THR and normalized to total protein. C: In parallel conditions, thrombin-mediated in vitro regulation of CSF2 mRNA in term decidual cells were treated with $E_{2}$ $\left(10^{-8} \mathrm{~mol} / \mathrm{L}\right), \mathrm{E}_{2}+\operatorname{THR}(1 \mathrm{U} / \mathrm{mL}), \mathrm{E}_{2}+$ dexamethasone $\left(D e x ; 10^{-7} \mathrm{~mol} / \mathrm{L}\right)$, $E_{2}+$ Dex + THR, $E_{2}+$ Organon $2058\left(\right.$ Org; $\left.10^{-7} \mathrm{~mol} / \mathrm{L}\right)$, or $E_{2}+$ Org + THR. Data are expressed as means \pm SEM $(\mathbf{A}-\mathbf{C}) . n=7(\mathbf{A}) ; n=8(\mathbf{B}) ; n=6(\mathbf{C})$. ${ }^{*} P<0.05$ versus $\mathrm{E}_{2} ;{ }^{\dagger} P<0.05$ versus $\mathrm{E}_{2}+\mathrm{MPA}^{\circ}{ }^{\ddagger} P<0.05$ versus $\mathrm{E}_{2}+\mathrm{THR}$; ${ }^{\S} P<0.05$ versus $\mathrm{E}_{2}+$ Dex; ${ }^{{ }^{\natural}} P<0.05$ versus $\mathrm{E}_{2}+$ Org. 


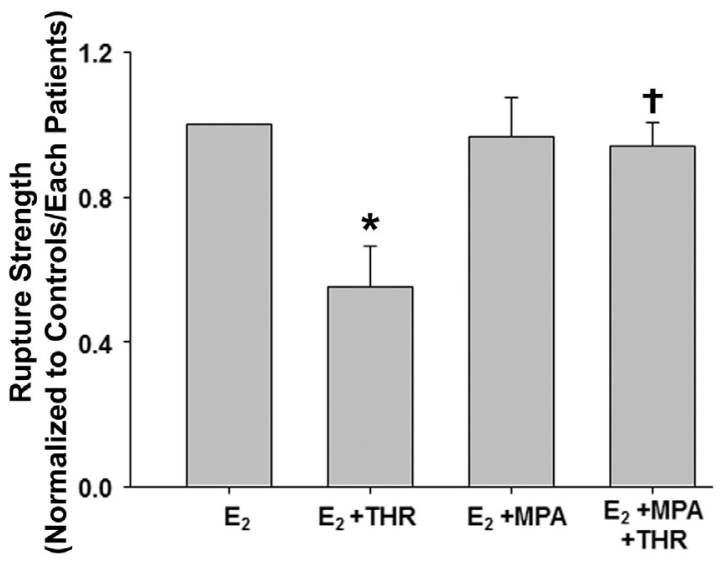

Figure 4 Thrombin (THR)-induced fetal membrane weakening. Condition media obtained from term decidual cells, as mentioned in Materials and Methods, treated with $10^{-8} \mathrm{~mol} / \mathrm{L}$ estradiol $\left(\mathrm{E}_{2}\right)$ used as a control, $\mathrm{E}_{2}+1 \mathrm{U} / \mathrm{mL}$ THR, $\mathrm{E}_{2}+10^{-7} \mathrm{~mol} / \mathrm{L}$ medroxyprogesterone acetate (MPA), or $\mathrm{E}_{2}+\mathrm{MPA}+\mathrm{THR}$, were applied to fetal membranes obtained from term placental specimens for 24 hours and fetal membrane strength was measured. Data are expressed as means \pm SEM. $n=4$. ${ }^{*} P<0.05$ versus $E_{2}$ as a control; ${ }^{\dagger} P<0.05$ versus $\mathrm{E}_{2}+$ THR.

weakening, showing that CSF-2 mediates both THR- and tumor necrosis factor- $\alpha$-induced fetal membrane weakening. ${ }^{11}$ To determine whether THR-induced TDC-secreted CSF- 2 contributes to fetal membrane weakening, TDCs were treated with $10^{-8} \mathrm{~mol} / \mathrm{L} \mathrm{E}_{2}$ as a control or $\mathrm{E}_{2}+10^{-7} \mathrm{~mol} / \mathrm{L}$ MPA to simulate the hormonal milieu of pregnancy, with or without $1 \mathrm{U} / \mathrm{mL}$ of THR for only 4 hours. To eliminate the direct effect of THR in TDC cultures, after 4 hours, TDCs were washed with phosphate-buffered saline and then incubated in control media, expanding on our previous results. ${ }^{19}$ CMS obtained from TDC-treated conditions after 24 hours of incubation revealed that THR pretreatment causes fetal membrane weakening $(P<0.05)$ and that the addition of MPA reversed this THR-mediated action (Figure 4). These results showing THR-induced TDC-secreted protein(s) (ie, CSF-2 reduces fetal membrane tensile strength) complement our previous observation that preincubation with CSF-2 neutralizing antibody blocks THR-induced fetal membrane weakening. ${ }^{19}$

\section{ERK1/2 and NF- $\kappa$ B Signaling Pathways Mediate THR-Induced CSF-2 Expression in TDC Cultures}

THR activates several intracellular signaling pathways, including NF- $\kappa \mathrm{B}$, ERK1/2, and p38 MAPKs, in TDCs. ${ }^{13}$ To identify signaling pathways responsible for THR-induced CSF2 expression, TDCs were treated with specific inhibitors of these potential intracellular signaling pathways. qPCR analysis in TDCs treated with $10^{-8} \mathrm{~mol} / \mathrm{L} \mathrm{E}_{2}+10^{-7}$ $\mathrm{mol} / \mathrm{L} \mathrm{MPA}+1 \mathrm{U} / \mathrm{mL}$ THR $\pm 2 \times 10^{-5} \mathrm{~mol} / \mathrm{L}$ PD 98059 , an ERK1/2 MAPK inhibitor, $2 \times 10^{-5} \mathrm{~mol} / \mathrm{L}$ SB203580, a p38 MAPK inhibitor, or $10^{-6} \mathrm{~mol} / \mathrm{L}$ Bay-III, an NF- $\kappa \mathrm{B}$ activation inhibitor, revealed that both the ERK1/2 MAPK and NF- $\kappa \mathrm{B}$ inhibitors, but not the p38 MAPK inhibitor, significantly reduced THR-induced CSF 2 mRNA levels in TDCs $(n=3 ; P<0.05)$ (Figure 5).

TDC-Secreted CSF-2 Activates STAT5 and Inhibits p38 MAPK Pathways in Trophoblasts

To identify mechanisms associated with TDC-secreted CSF2-mediated paracrine activation of intracellular signaling pathways in trophoblasts, BeWo cells (a trophoblast cell line) were treated with control or rh-CSF-2 $(10 \mathrm{ng} / \mathrm{mL})$ for 15 minutes and then subjected to immunoblotting to determine activation status of several crucial intracellular signaling molecules by evaluating both the total and phosphorylated forms. Immunoblotting results revealed a significant 3.7-fold increase in STAT5 phosphorylation $(P<0.05)$ and a 1.5 -fold reduction in $\mathrm{p} 38$ MAPK phosphorylation $(P<0.05)$ in BeWo cells treated with rh-CSF-2 versus control, whereas STAT3, ERK1/2, AKT, and NF- $\kappa \mathrm{B}$ p65 phosphorylation levels were not changed (Figure 6). To determine the presence of active STAT5 levels in chorionic extravillous trophoblasts, fetal membranes $(n=4)$ and decidua basalis $(n=3)$ were immunostained for active (phosphorylated) STAT5, which revealed phosphorylated STAT5 immunoreactivity in chorionic extravillous trophoblasts (Supplemental Figure S3), supporting induction of phosphorylated STAT5 by CSF-2 in choriodecidua explants.

\section{In Vitro Regulation of IL1B and MMP9 mRNA Levels by} CSF-2 in Choriodecidual Explants

Previous studies reported CSF-2 levels in amniotic fluid ranging from undetectable to $20 \mathrm{ng} / \mathrm{L}$ in pregnancies with

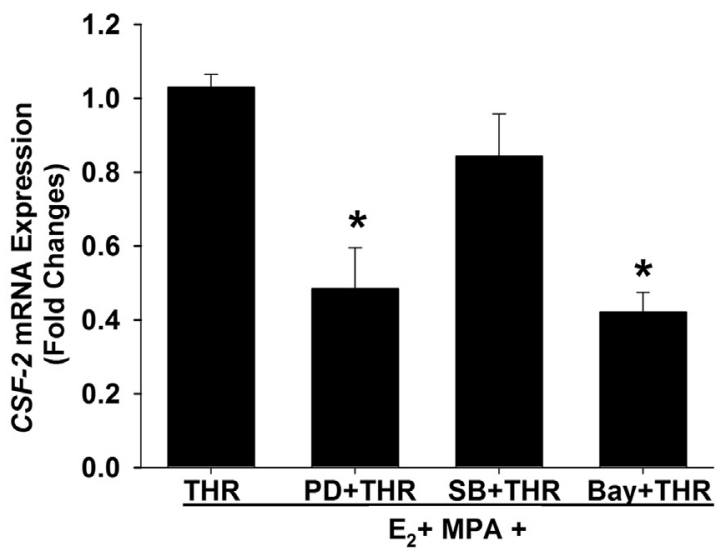

Figure 5 Thrombin (THR)-induced CSF2 expression in term decidual cultures is mediated by extracellular signal-regulated kinase (ERK) $1 / 2$ mitogen-activated protein kinase (MAPK) and NF- $\kappa B$ signaling pathways. CSF2 mRNA levels in term decidual cells treated with $1 \mathrm{U} / \mathrm{mL}$ THR, THR $+2 \times 10^{-5} \mathrm{~mol} / \mathrm{L}$ ERK1/2 MAPK inhibitor PD98059 (PD), THR $+2 \times 10^{-5} \mathrm{~mol} / \mathrm{L} \mathrm{p} 38$ MAPK inhibitor SB203580 (SB), or THR $+10^{-6}$ $\mathrm{mol} / \mathrm{L}$ NF- $\kappa$ B inhibitor Bay II-7082 (Bay) on thrombin-induced CSF2 mRNA expression. Data are expressed as means \pm SEM. $n=3$. ${ }^{*} P<0.05$ versus $\mathrm{E}_{2}+$ medroxyprogesterone acetate (MPA) + THR. 

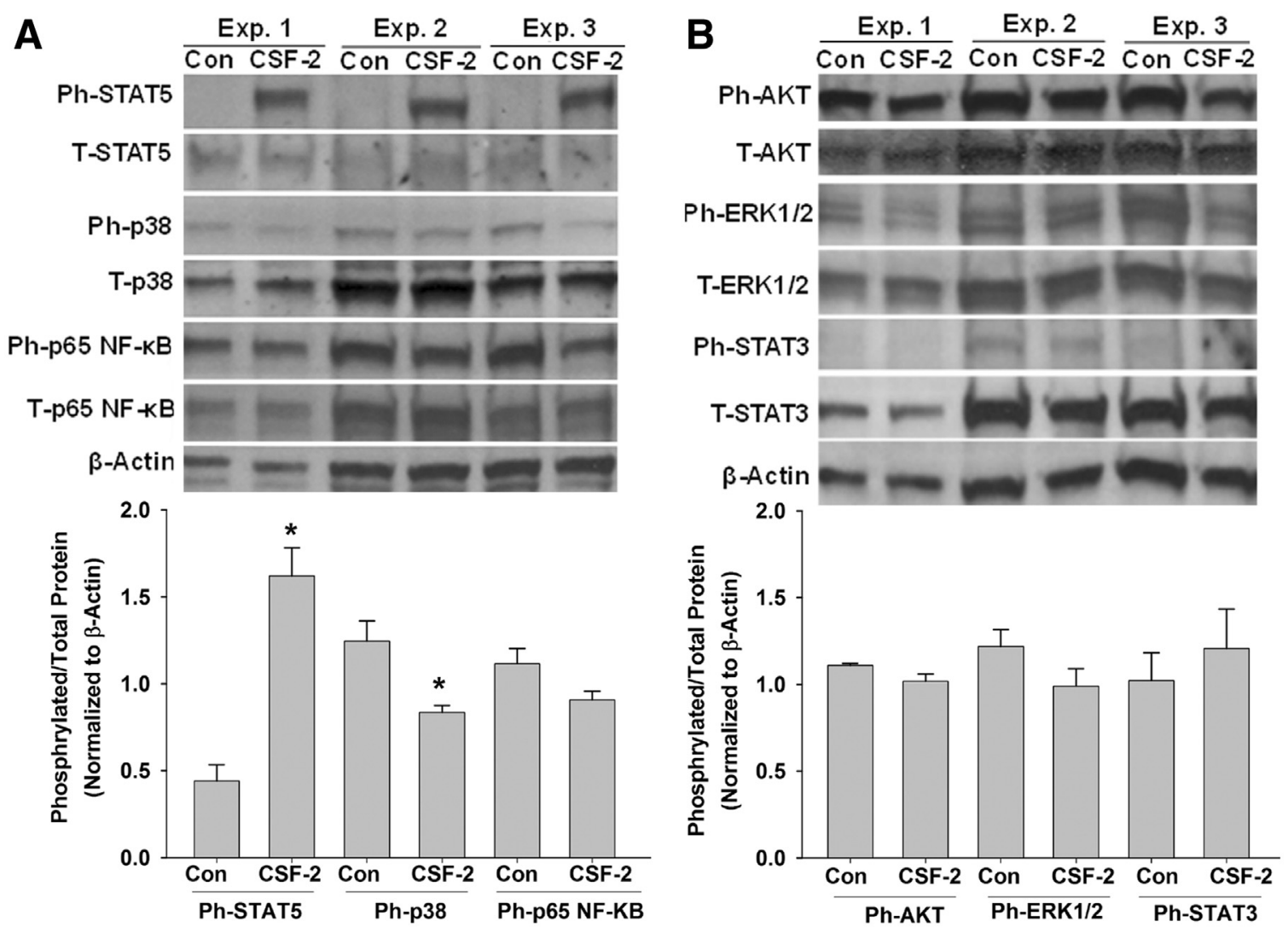

Figure 6 CSF-2-mediated activation of STAT5 and inhibition of p38 mitogen-activated protein kinase (MAPK) pathways in BeWo trophoblastic cell lines. Representative immunoblotting of BeWo cells, which were treated with control (Con) or $10 \mathrm{ng} / \mathrm{mL}$ recombinant CSF-2 for 15 minutes, displays phosphorylated (Ph-) or total (T-) levels of STAT5, p38 MAPK, p65 NF-KB subunit, AKT, extracellular signal-regulated kinase (ERK) 1/2 MAPK, and STAT3, as well as $\beta$-actin. Graphs display immunoblot densitometry readings obtained from experimental incubations of cells for phosphorylated/total forms of each protein after being normalized to $\beta$-actin. Data are expressed as means \pm SEM. $n=3$. ${ }^{*} P<0.05$ versus control. Exp., experiment.

intact membranes before 33 weeks of gestation, whereas CSF-2 levels in PPROM cases are significantly elevated, reaching up to $400 \mathrm{ng} / \mathrm{L}$ during the same period. ${ }^{20,21}$ To elucidate the pivotal role of TDC-secreted CSF-2 in abruption-associated PTBs, explant cultures of choriodecidual membranes obtained from a placenta at 33 weeks of pregnancy were treated with control or rh-CSF-2 (10 or 100 $\mathrm{ng} / \mathrm{mL}$ ) for 6 hours to evaluate mRNA levels of $M M P 3$,
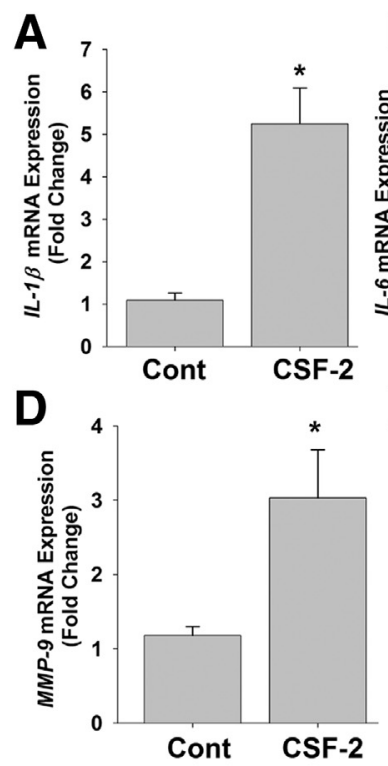
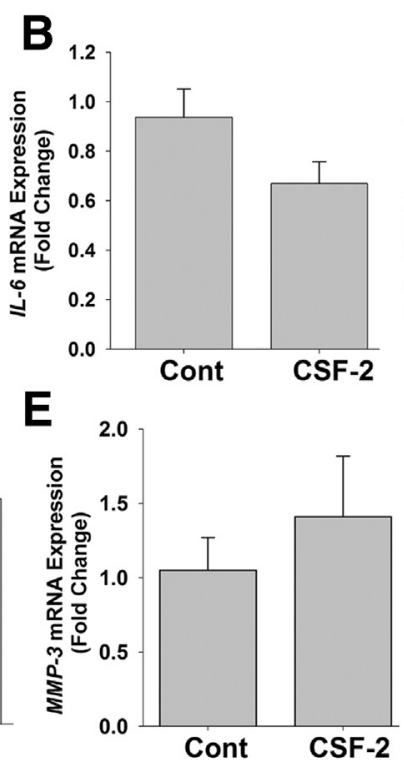
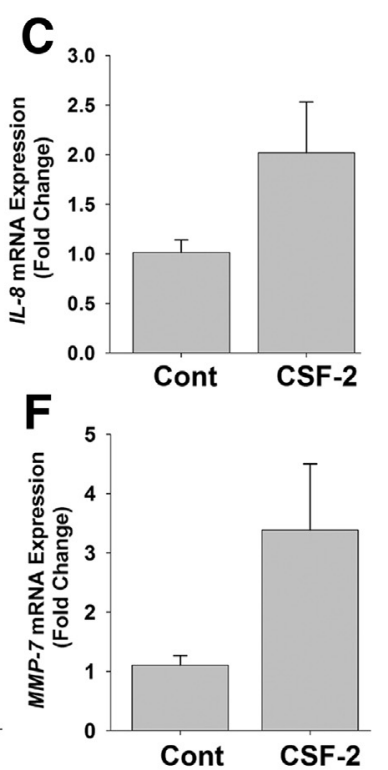

Figure 7 CSF-2 up-regulates IL-1 $\beta$ and matrix metalloproteinase (MMP)-9 expression in choriodecidual explant culture. Explant cultures were treated with vehicle [control (Cont)] or $100 \mathrm{ng} / \mathrm{mL}$ recombinant CSF-2 for 6 hours. Real-time quantitative PCR for IL1B, IL6, IL8, MMP9, MMP3, and MMP7 mRNA levels was measured and normalized to $\beta$-actin. A: Treatment of $100 \mathrm{ng} / \mathrm{mL}$ recombinant CSF-2 significantly increases $I L 1 B(P<0.05)$ mRNA levels versus control. $\mathbf{B}$ and $\mathbf{C}$ : Expression levels of $I L 6$ (B) and IL8 (C) do not change by CSF2. D: CSF-2 significantly increases MMP9 $(P<0.05)$ mRNA levels in choriodecidual explant culture versus control. $\mathbf{E}$ and $\mathbf{F}$ : $\mathrm{CSF}-2$ treatment does not change expression levels of MMP3 (E) and MMP7 (F) mRNAs. Data are expressed as means $\pm \operatorname{SEM}(\mathbf{A}-\mathbf{F}) .{ }^{*} P<0.05$ versus Cont. 


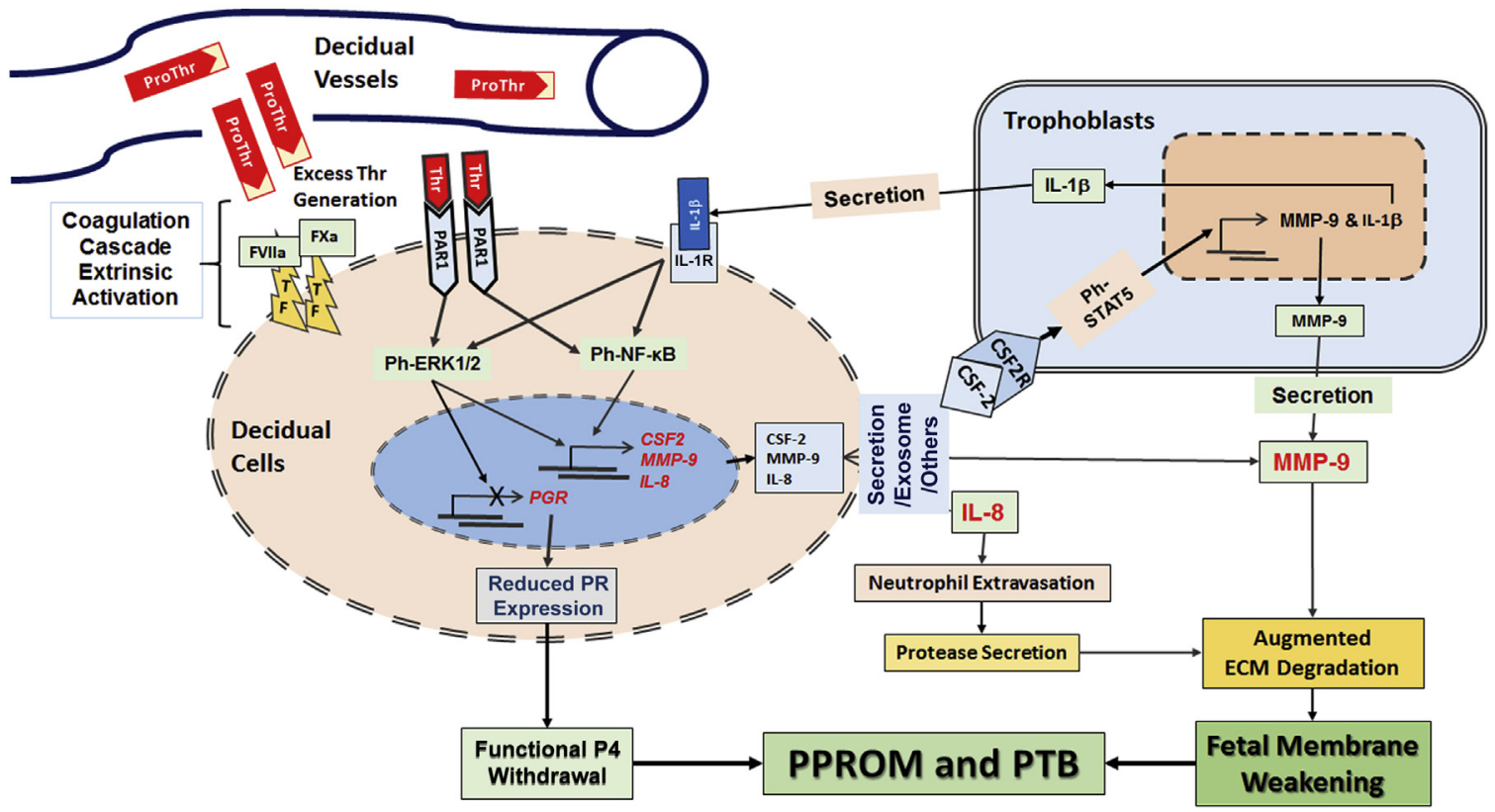

Figure 8 Bidirectional cross talk between decidual cells and trophoblasts induces abruption-associated preterm birth (PTB) and preterm premature rupture of the membranes (PPROM). In the presence of decidual hemorrhage, thrombin (Thr), generated from decidual cell-expressed tissue factor (TF), binding to protease-activated receptor (PAR)-1 receptors activates NF- $\kappa B$ and extracellular signal-regulated kinase (ERK) $1 / 2$ mitogen-activated protein kinase signaling pathways. Both pathways enhance production of several cytokines (IL-8 and CSF-2) to recruit neutrophils that elaborate various matrix metalloproteinases (MMPs) as well as other proteinases that promote fetal membrane rupture. Thr also suppresses decidual cell progesterone receptor (PR) levels by increasing ERK1/2 phosphorylation, resulting in functional progesterone withdrawal in the decidua that further induces MMP expression and decidual inflammation. Secreted CSF-2 (paracrine or exosome mediated) binding to CSF-2 receptor (CSF2R) expressing trophoblast cells activates the STAT5 signaling pathway to induce IL-1 $\beta$ and MMP-9 expression. In decidual cells, IL-1 $\beta$ activates NF- $\kappa B$ and other signaling pathways by enhancing expression of proinflammatory cytokines and MMPs and reduces PR levels to cause functional progesterone (P4) withdrawal. Taken together, functional P4 withdrawal, increased inflammatory cytokines (IL-8, IL-1 $\beta$, and CSF-2), and MMPs directly or indirectly trigger fetal membrane rupture, leading to PPROM and/or abruption-associated PTB. ECM, extracellular membrane; $\mathrm{Ph}-$, phosphorylated.

$M M P 7$, and $M M P 9$ as well as proinflammatory cytokines $I L I B, I L 6$, and IL8. This qPCR analysis revealed that $10 \mathrm{ng} /$ $\mathrm{mL}$ rh-CSF-2 treatment did not significantly change mRNA levels of any of these genes (Supplemental Figure S4), whereas $100 \mathrm{ng} / \mathrm{mL}$ rh-CSF-2 treatment significantly increased $I L 1 B$ (fourfold; $P<0.05$ ) and $M M P 9$ (threefold; $P<0.05$ ) levels in explant cultures versus control treatment (Figure 7, A and D); IL6,IL8, MMP3, and MMP7 levels did not change (Figure 7, B, C, E, and F).

\section{Discussion}

These results elucidate pathways contributing to abruptionassociated PTB. Our observations at the maternal-fetal interface demonstrate CSF-2 immunoreactivity in decidual cell cytoplasm and its receptor, CSF2RA, in trophoblast cell membranes, suggesting the existence of a potential paracrine mechanism whereby decidual cell-secreted CSF-2 binds to trophoblast-expressed CSF2R. In vitro observations confirming significantly higher expression of $C S F 2 \mathrm{mRNA}$ in TDCs and CSF2RA mRNA in CTB and STB cultures support this proposed mechanism. Furthermore, THRtreated TDC-secreted CSF-2 significantly weakened fetal membranes obtained from term placentas; and using signaling pathway inhibitors, NF- $\kappa \mathrm{B}$ and ERK1/2 MAPK, documented inducers of inflammatory gene expression, ${ }^{22}$ were identified as main signaling meditators of THRinduced CSF 2 gene expression in TDCs.

Strong evidence supports the association of decidual hemorrhage with approximately $10 \%$ of all bleeding-related PTBs. In most cases, vaginal bleeding arises from hemorrhage into the decidua basalis (placental abruption) or decidua parietalis (subchorionic hematoma). ${ }^{17}$ Decidual hemorrhage complicates almost $40 \%$ of PTBs due to preterm labor with intact membranes and PPROM between 22 and 38 weeks versus $0.8 \%$ post-term delivery. ${ }^{10}$ Despite its large public health impact, the precise mechanisms causing PTB are incompletely understood, limiting development of preventive and therapeutic interventions.

In most mammals, labor is initiated by a rapid decrease in circulating maternal P4 levels. In humans, however, elevated P4 levels in maternal plasma as well as fetal and amniotic fluid are sustained until delivery of the fetalplacental unit, suggesting that parturition is initiated in response to functional P4 withdrawal elicited by a decline in progesterone receptor levels and/or a shift in the progesterone receptor isoforms. ${ }^{12,13,18,23-25}$ THR contributes to PPROM, preterm labor, and abruption-associated PTB by multiple pathways ${ }^{26}$ summarized in Figure 8. These include 
THR: i) activation of ERK1/2 MAPK signaling and subsequent inhibition of progesterone receptor mRNA and protein expressions as well as reduction of the binding of progesterone receptor to its DNA response element in TDCs, leading to functional P4 withdrawal $^{13}$; ii) upregulation of extracellular matrix-degrading $M M P 1$ and $M M P 9^{27-29}$ mRNA transcription and protein secretion, contributing to fetal membrane weakening; and iii) upregulation of IL-8 expression levels by promoting neutrophil trafficking into the hemorrhagic decidua by activating NF- $\kappa \mathrm{B}$ signaling pathways ${ }^{30}$ (Figure 8 ).

Mounting evidence indicates that exosomes are one of the key mediators of indirect cell-cell interactions in the pathophysiological regulation of the placenta. ${ }^{31-33}$ Thus, exosomes may mediate paracrine CSF2-CSF2R interactions between decidual cells and trophoblasts at the maternal fetal interface and/or choriodecidua of the fetal membrane. As the role played by increased neutrophil infiltration into the maternal-fetal interface in PTB became more evident, the current findings shed light on the involvement of THR-induced TDC-secreted CSF-2 in fetal membrane weakening, PPROM, and PTB. ${ }^{11,19,34}$ The growing body of evidence supporting the association between elevated THR levels with abruptionassociated $\mathrm{PTB}^{13,26}$ prompted this study to explore the involvement of CSF-2 in abruption-associated PTB and the associated intracellular signaling pathways involved in the pathophysiological role played by CSF-2.

Colony-stimulating factors are well-established hematopoietic growth factors. Recent studies showed that CSF-2 also acts on nonhematopoietic cell types, including astrocytes, ${ }^{35}$ cardiomyocytes, ${ }^{36}$ and trophoblasts. ${ }^{37}$ Chemotactic properties of CSF-2 include recruitment of monocytes ${ }^{38}$ as well as neutrophils. ${ }^{39,40}$ The current results revealed the presence of significantly higher CSF-2 expression at the maternal-fetal interface of abruption-associated or idiopathic PTBs versus term specimens. Similar CSF-2 levels in abruption-associated and idiopathic PTB specimens suggest that CSF-2-mediated paracrine signaling is a common contributor to PTB. In cases of abruption-associated PTB, the current in vitro observations suggest that THR is the primary factor responsible for the increase in CSF-2 expression. On the other hand, the factors responsible for increased CSF-2 expression in idiopathic PTB are unknown and require further investigation but could reflect occult hemorrhage. $^{41,42}$

The current in vitro results confirm our immunohistochemical results that TDC-derived THR induces CSF2 mRNA and protein secretion. THR-induced CSF-2 levels were significantly blunted by treatment of either MPA or dexamethasone, pure glucocorticoid, or Organon 2058 as a pure progestin, suggesting the potential protective effect of P4 or glucocorticoid against abruption-associated PTB; and THR-treated TDC-secreted CSF-2 significantly weakened fetal membranes obtained from term placentas. The current results support our previous study demonstrating that in the choriodecidua, THR induces fetal membrane weakening by elevating CSF-2 levels, which is inhibited by blockade of CSF-2 action with a neutralizing antibody. ${ }^{11}$

By using specific signaling pathway inhibitor(s), the current study identified NF- $\mathrm{BB}$ and ERK1/2 MAPK, documented inducers of inflammatory gene expression, ${ }^{22}$ as main signaling meditators of THR-induced CSF2 gene expression in TDCs. Moreover, the current in vitro observations in BeWo cells, demonstrating activation of STAT5 and inhibition of p38 MAPK signaling by rh-CSF-2, suggest that THR-induced TDC-secreted CSF-2 acts as a paracrine inducer in trophoblasts that may contribute to fetal membrane weakening and thus induce abruption-associated PTB. This suggestion was confirmed in choriodecidual explant cultures in which treatment with rh-CSF-2 enhances $I L 1 B$ and MMP9 mRNA expression. These results suggest that excess CSF-2 acts as a critical common mediator of PTB by contributing to abruption-induced inflammation and fetal membrane weakening (Figure 8).

In conclusion, current immunohistochemical and in vitro results suggest that THR-induced excess CSF-2 levels trigger a paracrine signaling in adjacent trophoblast that induces inflammation and fetal membrane weakening, contributing to abruption-associated PTB. Considered together, these observations suggest that CSF-2-mediated signaling pathways in TDCs or trophoblasts (ie, ERK1/2, NF- $\kappa \mathrm{B}$, or STAT5) are likely to be one of the mechanisms involved in abruption-associated PTB.

\section{Acknowledgments}

We thank Dr. Seth Guller (Yale College of Medicine) for providing cytotrophoblasts and syncytiotrophoblasts; and Dr. Hana Totary-Jain (University of South Florida, Morsani College of Medicine) for providing BeWo cells.

\section{Supplemental Data}

Supplemental material for this article can be found at https://doi.org/10.1016/j.ajpath.2019.10.020.

\section{References}

1. Reed BG, Carr BR, The Normal Menstrual Cycle and the Control of Ovulation: Endotext. Edited by De Groot LJ, Chrousos G, Dungan K, Feingold KR, Grossman A, Hershman JM, Koch C, Korbonits M, McLachlan R, New M, Purnell J, Rebar R, Singer F, Vinik A. South Dartmouth, MA: MDText.com, Inc., 2000

2. Lockwood CJ, Krikun G, Papp C, Toth-Pal E, Markiewicz L, Wang EY, Kerenyi T, Zhou X, Hausknecht V, Papp Z, Schatz F: The role of progestationally regulated stromal cell tissue factor and type-1 plasminogen activator inhibitor (PAI-1) in endometrial hemostasis and menstruation. Ann N Y Acad Sci 1994, 734:57-79

3. Mackman N, Tilley RE, Key NS: Role of the extrinsic pathway of blood coagulation in hemostasis and thrombosis. Arterioscler Thromb Vasc Biol 2007, 27:1687-1693

4. Lockwood CJ, Murk W, Kayisli UA, Buchwalder LF, Huang ST, Funai EF, Krikun G, Schatz F: Progestin and thrombin regulate tissue 
factor expression in human term decidual cells. J Clin Endocrinol Metab 2009, 94:2164-2170

5. Downes KL, Grantz KL, Shenassa ED: Maternal, labor, delivery, and perinatal outcomes associated with placental abruption: a systematic review. Am J Perinatol 2017, 34:935-957

6. Norman SM, Odibo AO, Macones GA, Dicke JM, Crane JP, Cahill AG: Ultrasound-detected subchorionic hemorrhage and the obstetric implications. Obstet Gynecol 2010, 116:311-315

7. Hossain R, Harris T, Lohsoonthorn V, Williams MA: Risk of preterm delivery in relation to vaginal bleeding in early pregnancy. Eur $\mathrm{J}$ Obstet Gynecol Reprod Biol 2007, 135:158-163

8. DeRoo L, Skjaerven R, Wilcox A, Klungsoyr K, Wikstrom AK, Morken NH, Cnattingius S: Placental abruption and long-term maternal cardiovascular disease mortality: a population-based registry study in Norway and Sweden. Eur J Epidemiol 2016, 31:501-511

9. Pariente G, Shoham-Vardi I, Kessous R, Sherf M, Sheiner E: Placental abruption as a significant risk factor for long-term cardiovascular mortality in a follow-up period of more than a decade. Paediatr Perinat Epidemiol 2014, 28:32-38

10. Salafia CM, Lopez-Zeno JA, Sherer DM, Whittington SS, Minior VK, Vintzileos AM: Histologic evidence of old intrauterine bleeding is more frequent in prematurity. Am J Obstet Gynecol 1995, 173:1065-1070

11. Kumar D, Springel E, Moore RM, Mercer BM, Philipson E, Mansour JM, Mesiano S, Schatz F, Lockwood CJ, Moore JJ: Progesterone inhibits in vitro fetal membrane weakening. Am J Obstet Gynecol 2015, 213:520.e1-520.e9

12. Lockwood CJ, Stocco C, Murk W, Kayisli UA, Funai EF, Schatz F: Human labor is associated with reduced decidual cell expression of progesterone, but not glucocorticoid, receptors. J Clin Endocrinol Metab 2010, 95:2271-2275

13. Lockwood CJ, Kayisli UA, Stocco C, Murk W, Vatandaslar E, Buchwalder LF, Schatz F: Abruption-induced preterm delivery is associated with thrombin-mediated functional progesterone withdrawal in decidual cells. Am J Pathol 2012, 181:2138-2148

14. Sarno JL, Schatz F, Lockwood CJ, Huang ST, Taylor HS: Thrombin and interleukin-1beta regulate HOXA10 expression in human term decidual cells: implications for preterm labor. J Clin Endocrinol Metab 2006, 91:2366-2372

15. Tang Z, Tadesse S, Norwitz E, Mor G, Abrahams VM, Guller S: Isolation of hofbauer cells from human term placentas with high yield and purity. Am J Reprod Immunol 2011, 66:336-348

16. Lee MJ, Wang Z, Yee H, Ma Y, Swenson N, Yang L, Kadner SS, Baergen RN, Logan SK, Garabedian MJ, Guller S: Expression and regulation of glucocorticoid receptor in human placental villous fibroblasts. Endocrinology 2005, 146:4619-4626

17. Han CS, Schatz F, Lockwood CJ: Abruption-associated prematurity. Clin Perinatol 2011, 38:407-421

18. Guzeloglu-Kayisli O, Kayisli UA, Semerci N, Basar M, Buchwalder LF, Buhimschi CS, Buhimschi IA, Arcuri F, Larsen K, Huang JS, Schatz F, Lockwood CJ: Mechanisms of chorioamnionitisassociated preterm birth: interleukin-1beta inhibits progesterone receptor expression in decidual cells. J Pathol 2015, 237:423-434

19. Kumar D, Moore RM, Nash A, Springel E, Mercer BM, Philipson E, Mansour JM, Moore JJ: Decidual GM-CSF is a critical common intermediate necessary for thrombin and TNF induced in-vitro fetal membrane weakening. Placenta 2014, 35:1049-1056

20. Bry K, Hallman M, Teramo K, Waffarn F, Lappalainen U: Granulocyte-macrophage colony-stimulating factor in amniotic fluid and in airway specimens of newborn infants. Pediatr Res 1997, 41: 105-109

21. Cobo T, Kacerovsky M, Palacio M, Hornychova H, Hougaard DM, Skogstrand K, Jacobsson B: Intra-amniotic inflammatory response in subgroups of women with preterm prelabor rupture of the membranes. PLoS One 2012, 7:e43677

22. Newton K, Dixit VM: Signaling in innate immunity and inflammation. Cold Spring Harb Perspect Biol 2012, 4:a006049
23. Patel B, Peters GA, Skomorovska-Prokvolit Y, Yi L, Tan H, Yousef A, Wang J, Mesiano S: Control of progesterone receptor-A transrepressive activity in myometrial cells: implications for the control of human parturition. Reprod Sci 2018, 25:214-221

24. Nadeem L, Shynlova O, Matysiak-Zablocki E, Mesiano S, Dong X, Lye S: Molecular evidence of functional progesterone withdrawal in human myometrium. Nat Commun 2016, 7:11565

25. Ackerman WE, Summerfield TL, Mesiano S, Schatz F, Lockwood CJ, Kniss DA: Agonist-dependent downregulation of progesterone receptors in human cervical stromal fibroblasts. Reprod Sci 2016, 23:112-123

26. Schatz F, Guzeloglu-Kayisli O, Arlier S, Kayisli UA, Lockwood CJ: The role of decidual cells in uterine hemostasis, menstruation, inflammation, adverse pregnancy outcomes and abnormal uterine bleeding. Hum Reprod Update 2016, 22:497-515

27. Lockwood CJ, Basar M, Kayisli UA, Guzeloglu-Kayisli O, Murk W, Wang J, De Paz N, Shapiro JP, Masch RJ, Semerci N, Huang SJ, Schatz F: Interferon-gamma protects first-trimester decidual cells against aberrant matrix metalloproteinases 1,3 , and 9 expression in preeclampsia. Am J Pathol 2014, 184:2549-2559

28. Rosen T, Schatz F, Kuczynski E, Lam H, Koo AB, Lockwood CJ: Thrombin-enhanced matrix metalloproteinase-1 expression: a mechanism linking placental abruption with premature rupture of the membranes. J Matern Fetal Neonatal Med 2002, 11:11-17

29. Stephenson CD, Lockwood CJ, Ma Y, Guller S: Thrombin-dependent regulation of matrix metalloproteinase (MMP)-9 levels in human fetal membranes. J Matern Fetal Neonatal Med 2005, 18:17-22

30. Lockwood CJ, Toti P, Arcuri F, Paidas M, Buchwalder L, Krikun G, Schatz F: Mechanisms of abruption-induced premature rupture of the fetal membranes: thrombin-enhanced interleukin-8 expression in term decidua. Am J Pathol 2005, 167:1443-1449

31. Rice TF, Donaldson B, Bouqueau M, Kampmann B, Holder B: Macrophage- but not monocyte-derived extracellular vesicles induce placental pro-inflammatory responses. Placenta 2018, 69:92-95

32. Truong G, Guanzon D, Kinhal V, Elfeky O, Lai A, Longo S, Nuzhat Z, Palma C, Scholz-Romero K, Menon R, Mol BW, Rice GE, Salomon C: Oxygen tension regulates the miRNA profile and bioactivity of exosomes released from extravillous trophoblast cells: liquid biopsies for monitoring complications of pregnancy. PLoS One 2017, 12:e0174514

33. Cuffe JSM, Holland O, Salomon C, Rice GE, Perkins AV: Review: placental derived biomarkers of pregnancy disorders. Placenta 2017, $54: 104-110$

34. Huang SJ, Zenclussen AC, Chen CP, Basar M, Yang H, Arcuri F, Li M, Kocamaz E, Buchwalder L, Rahman M, Kayisli U, Schatz F, Toti P, Lockwood CJ: The implication of aberrant GM-CSF expression in decidual cells in the pathogenesis of preeclampsia. Am J Pathol 2010, 177:2472-2482

35. Imitola J, Rasouli J, Watanabe F, Mahajan K, Sharan AD, Ciric B, Zhang GX, Rostami A: Elevated expression of granulocytemacrophage colony-stimulating factor receptor in multiple sclerosis lesions. J Neuroimmunol 2018, 317:45-54

36. Postiglione L, Montagnani S, Ladogana P, Castaldo C, Di Spigna G, Bruno EM, Turano M, De Santo L, Cudemo G, Cocozza S, de Divitiis O, Rossi G: Granulocyte macrophage-colony stimulating factor receptor expression on human cardiomyocytes from end-stage heart failure patients. Eur J Heart Fail 2006, 8:564-570

37. Jokhi PP, King A, Jubinsky PT, Loke YW: Demonstration of the low affinity alpha subunit of the granulocyte-macrophage colony-stimulating factor receptor (GM-CSF-R alpha) on human trophoblast and uterine cells. J Reprod Immunol 1994, 26:147-164

38. Shi Y, Liu CH, Roberts AI, Das J, Xu G, Ren G, Zhang Y, Zhang L, Yuan ZR, Tan HS, Das G, Devadas S: Granulocyte-macrophage colony-stimulating factor (GM-CSF) and T-cell responses: what we do and don't know. Cell Res 2006, 16:126-133

39. Khajah M, Millen B, Cara DC, Waterhouse C, McCafferty DM: Granulocyte-macrophage colony-stimulating factor (GM-CSF): a 
chemoattractive agent for murine leukocytes in vivo. J Leukoc Biol 2011, 89:945-953

40. Zaret BS: Lightning streaks of Moore: a cause of recurrent stereotypic visual disturbance. Neurology 1985, 35:1078-1081

41. Rosen T, Kuczynski E, O’Neill LM, Funai EF, Lockwood CJ: Plasma levels of thrombin-antithrombin complexes predict preterm premature rupture of the fetal membranes. J Matern Fetal Med 2001, 10: 297-300

42. Chaiworapongsa T, Espinoza J, Yoshimatsu J, Kim YM, Bujold E, Edwin S, Yoon BH, Romero R: Activation of coagulation system in preterm labor and preterm premature rupture of membranes. J Matern Fetal Neonatal Med 2002, 11:368-373 